\title{
Effect of drying and harvest time on the physicochemical properties of the most common Korean persimmon leaves
}

\author{
Abul Hossain ${ }^{1}$, Hey-Kyung Moon ${ }^{2}$, Jong-Kuk Kim ${ }^{1 *}$ \\ ${ }^{1}$ Department of Food and Food Service Industry, Kyungpook National University, Sangju 37224, Korea \\ ${ }^{2}$ Center for Scientific Instument, Kyungpook National University, Sangju 37224, Korea
}

\begin{abstract}
Persimmon is a plant that is native to the Republic of Korea. It leaves are rich in antioxidants and minerals. This study set out to investigate the moisture, color, vitamin $\mathrm{C}$, and mineral contents of five of the most common Korean persimmon leaves ('Sangju-dungsi', 'Sangam-dungsi', 'Cheongdobansi', 'Gabjubaekmok,' and 'Suhong'), and how they varied with the applied drying technique (freeze-drying or hot-air drying at $100{ }^{\circ} \mathrm{C}$ for 30 min) and harvesting time (late May or late June). Persimmon leaves were first collected, and then blanched and dried. Our results revealed that freeze-drying was the most effective method in terms of the mineral content, while no significant difference in the vitamin $\mathrm{C}$ content was observed regardless of the drying method. The concentration of $\mathrm{Mg}$, $\mathrm{Ca}$, $\mathrm{K}$, and Mn increased from May to June, while the opposite trend was observed for $\mathrm{Na}, \mathrm{Fe}, \mathrm{Cu}$, and $\mathrm{Zn}$. Persimmon leaves collected in late May had a higher vitamin $C$ content than those harvested in late June. Ultimately, the 'Sangam-dungsi' persimmon leaf was found to have the highest mineral content, whereas 'Gabjubaekmok' leaves were richer in color (lightness, redness, and yellowness) and had the highest vitamin $\mathrm{C}$ content among the analyzed cultivars.
\end{abstract}

Key words : persimmon leaf, vitamin $\mathrm{C}$, mineral nutrients, drying treatment, harvesting time, cultivar

\section{Introduction}

Persimmon (Diospyros kaki) is a member of the Ebenaceae family and is cultivated all over Eastern Asia. The fruit of the persimmon is eaten either fresh or dried, while the leaves are a staple ingredient in pharmaceuticals, cosmetics, and beverages. The leaf is commonly used to make a tea, effects for ailments including frostbite and, paralysis, while it is also used to treat bleeding and burns (1).

Persimmon leaf contains large amounts of bioactive compounds such as flavonoids, phenols, tannins, caffeine, chlorophyll, and ascorbic acid (vitamin C) (1,2). Ascorbic acid is an odorless white crystalline material which is soluble in water due to its polar characteristics. Generally, ascorbic acid is found in fruits, vegetables, as well as teas, and has

*Corresponding author. E-mail : kjk@knu.ac.kr

Phone : 82-54-530-1305, Fax : 82-54-530-1309

Received 14 June 2017; Revised 25 August 2017; Accepted 6 July 2018.

Copyright (c) The Korean Society of Food Preservation. All rights reserved. long been associated with the prevention of diseases such as scurvy. Ascorbic acid is easily degraded, however, as a result of several factors such as temperature, $\mathrm{pH}$, light intensity, oxygen, enzymes, metallic catalyzers, relative humidity, physical damage, frost damage, adverse handling, and storage conditions $(3,4)$.

Moreover, it is important to recognize the seasonal changes in the mineral contents of the leaves and identify the optimum harvesting time. Leaf-nutrient analysis plays an important role in evaluating future fertilization requirements (5) and also plays a significant part in the growth and development of plants and fruit quality. Thus, it is important to be aware of the fluctuations in the mineral contents of persimmon leaves in order to determine the optimum harvesting time. Not least, macro- and micro-nutrients play an active role in the prevention and treatment of atherosclerosis as well as coronary heart diseases $(6,7)$.

The drying method can affect the quantity and quality of the final product. Drying is necessary to ensure the physical, chemical, and microbiological stability of the harvested persimmon leaves. Any drying process should be capable 
of preserving the nutrient content, while facilitating the easy storage and transportation of the leaves. Hot-air drying and freeze-drying are the most common drying techniques used in food preservation. Freeze-drying is the optimum drying method for preserving e-nutritional value as well as color. However, both methods affect the quality and availability of the minerals, vitamins, and other nutrients to different degrees. Therefore, it is important to identify the optimum drying technique to ensure the retention of the ascorbic acid as well as the mineral content.

To the best of our knowledge, only a limited number of studies have examined the physicochemical properties of persimmon leaves. The present study set out to determine the moisture, color, vitamin $\mathrm{C}$, and mineral contents of Korean persimmon leaves, the effect of different drying techniques (hot-air drying at $100^{\circ} \mathrm{C}$ for $30 \mathrm{~min}$ and freeze drying), differences between the cultivars ('Sangju-dungsi', 'Sangam-dungsi', 'Cheongdobansi', 'Gabjubaekmok,' and 'Suhong'), and the optimum harvest time ( $25^{\text {th }}$ May vs. $25^{\text {th }}$ June).

\section{Materials and methods}

\section{Chemicals and reagents}

L-ascorbic acid and meta-phosphoric acid were purchased from Sigma-Aldrich Chemicals Co. (St. Louis, MO, USA), 2, 4-dinitrophenyl hydrazine was obtained from TCI Co., Ltd. (Tokyo, Japan), sulfuric acid and acetic acid were purchased from Duksan Pure Chemicals Co., Ltd. (Ansan, Korea), and nitric acid was acquired from Daejung Chemical \& Metal Co., Ltd. (Siheung, Korea). All the other chemicals were of analytical grade.

\section{Samples}

For each cultivar, 30 trees were selected, and leaf samples were collected. The leaves of four cultivars (Sangju-dungsi', 'Sangam-dungsi', 'Gabjubaekmok', and 'Suhong') of persimmon were collected from the Sangju Persimmon Experiment Station, South Korea on $25^{\text {th }}$ May (flowering stage) and again on the $25^{\text {th }}$ June (fruiting stage). At the same time, 'Cheongdobansi' persimmon leaves were harvested in Cheongdo, Korea.

\section{Drying of raw material}

The persimmon leaves were blanched at $100^{\circ} \mathrm{C}$ for $2 \mathrm{~min}$ and were then dried using either of two drying methods: (i)
Hot-air drying at $100^{\circ} \mathrm{C}$ for $30 \mathrm{~min}$; (ii) Freeze-drying for $72 \mathrm{~h}$ in a vacuum freeze dryer (8).

\section{Moisture content}

The moisture content was determined using the AOAC, 2000 method (9).

\section{Color measurement}

The color was measured using a color-difference meter (UltraScan Pro Spectrophotometer, HunterLab Inc., Reston, VA, USA). Black and white tiles were used as standards to calibrate the device before the analysis. Dried persimmon leaf powder was then transferred to a measuring cell and lightness $\left(\mathrm{L}^{*}\right)$, redness $\left(\mathrm{a}^{*}\right.$, red-green), and yellowness $\left(\mathrm{b}^{*}\right.$, yellow-blue) were determined using the computerized system.

\section{Determination of vitamin $\mathrm{C}$ content}

The vitamin $\mathrm{C}$ content was determined using the method devised by Khan et al. (10) with slight modifications. Briefly, $5 \mathrm{~g}$ of sample were homogenized in $25 \mathrm{~mL}$ of $3 \%$ metaphosphoric acid (MPA) $8 \%$ acetic acid (AA) solution. The resulting solution was then transferred to a, $50 \mathrm{~mL}$ volumetric jar and shaken gently to homogenize the solution. It was then diluted up to the $50 \mathrm{~mL}$ mark by adding more of the same MPA-AA solution. The resulting solution was filtered and then 4-5 drops of bromine water were added until the solution developed a color. Next, a few drops of $10 \%$ thiourea $\left(\mathrm{CH}_{4} \mathrm{~N}_{2} \mathrm{~S}\right)$ solution were added to eliminate the extra bromine, thus producing a clear solution. This was coupled with 2, 4-dinitrophenyl hydrazine for $1 \mathrm{~h}$ and then treated with $85 \%$ sulfuric acid. Then, the absorbance was measured using a spectrophotometer (T60U, PG Instruments, Leicestershire, UK) at $521 \mathrm{~nm}$. Standard crystalline ascorbic acid within a concentration array of 0-500 ppm was used to plot the standard curve for the vitamin $\mathrm{C}$ content.

\section{Determination of mineral content}

The mineral content was evaluated according to the method devised by Bond et al. (11) with some modifications. First, $2 \mathrm{~g}$ of each sample were mixed with $20 \mathrm{~mL}$ of concentrated nitric acid and placed on a hot-plate at $90^{\circ} \mathrm{C}$ overnight to volatilize the nitric acid. After cooling, the mixture was diluted to a final volume of $50 \mathrm{~mL}$ by adding distilled water. Then, the samples were examined using an ICP spectrometer (iCAP7600 Duo, Themo Scientific, Shanghai, China) to determine the mineral content. The instrument was calibrated using known standards for each mineral. 


\section{Statistical analysis}

The data were reported as the mean \pm SD of three measurements. Analysis of variance (ANOVA) was performed to estimate the effect of the process variables (harvest time, drying method, and leaf variety). Any significant difference $(\mathrm{p}<0.05)$ between means was analyzed by using the Statistical Analysis System (SAS 9.3) program.

\section{Results and discussion}

\section{Moisture content}

Moisture plays a key role in the growth and development of leaf pests and bacteria. Leaves can be made safe for consumption by eliminating moisture and thus minimizing the effects of pathogens.

Therefore, it is important to reduce the moisture content to the desired level. The moisture content of persimmon leaf powder was found to be highly dependent on the drying treatments (Table 1). Fresh persimmon leaves have a moisture content of around $75-80 \%$ whereas the powdered dried leaves, treated by hot-air and freeze-drying, have moisture contents of ca. $10 \%$ and $4 \%$, respectively. Freeze-drying resulted in a lower moisture content than hot-air drying $(\mathrm{p}<0.05)$. In contrast, powdered 'Suhong' leaf had the highest moisture content of all the cultivars, regardless of the harvesting time. Moreover, a similar moisture content was detected in the other analyzed cultivars collected at both harvesting times, although there were variations in the moisture content according to the cultivar.

Table 1. Moisture content (\%) of powdered persimmon leaves, produced by hot-air drying and freeze-drying

\begin{tabular}{ccccc} 
& & & \multicolumn{2}{c}{ (unit: \%) } \\
\hline Cultivar & $25^{\mathrm{b}}$ May (flowering) & \multicolumn{2}{c}{$25^{\mathrm{bh}}$ June (fruiting) } \\
\hline Sangiu-dungsi & $8.58 \pm 0.16^{2) \mathrm{b} 3)}$ & $4.28 \pm 0.01^{\mathrm{cb}}$ & $9.25 \pm 0.16^{\mathrm{b}}$ & $3.56 \pm 0.12^{\mathrm{ba}}$ \\
Sangam-dungsi & $9.28 \pm 0.27^{\mathrm{b}}$ & $4.33 \pm 0.14^{\mathrm{b}}$ & $10.55 \pm 0.18^{\mathrm{a}}$ & $3.16 \pm 0.15^{\mathrm{b}}$ \\
Cheongdobansi & $8.64 \pm 0.06^{\mathrm{b}}$ & $3.83 \pm 0.17^{\mathrm{c}}$ & $7.35 \pm 0.26^{\mathrm{c}}$ & $3.15 \pm 0.03^{\mathrm{b}}$ \\
Gabjubaekmok & $9.76 \pm 0.09^{\mathrm{b}}$ & $3.91 \pm 0.24^{\mathrm{cb}}$ & $9.80 \pm 0.17^{\mathrm{ba}}$ & $3.53 \pm 0.10^{\mathrm{ba}}$ \\
Suhong & $11.52 \pm 0.77^{\mathrm{a}}$ & $4.99 \pm 0.01^{\mathrm{a}}$ & $10.66 \pm 0.09^{\mathrm{a}}$ & $3.72 \pm 0.18^{\mathrm{a}}$ \\
\hline
\end{tabular}

${ }^{1)} \mathrm{HAD}$, hot-air drying, FD, freeze-drying.

${ }^{2}$ Results are expressed as mean \pm standard error of three measurements ( $\left.n=3\right)$.

${ }^{3)}$ Lower case letters within column of the different cultivars across drying method are significantly different $(\mathrm{p}<0.05)$.

\section{Color}

There are many pigments such as chlorophyll, anthocyanins, carotene, and xanthophyll which are responsible for the change in the color of the leaves during the growing season. The color, described in terms of the Hunter $L^{*}, a^{*}$, and $b^{*}$ values, of the dried persimmon leaves is presented in Table 2 . No statistical differences in the $\mathrm{L}^{*}$ and $b^{*}$ values were observed between the flowering (late May) and fruiting (late June) stages, whereas the highest $a^{*}$ value was obtained in the flowering stage.

The $L^{*}$ value of the freeze-dried leaves was the highest, while the leaves dried with hot air produced the lowest $\mathrm{L}^{*}$ value $(p<0.05)$. Similar trends were observed for the $b^{*}$ value, with the freeze-dried samples revealing the highest $b^{*}$ value, while the opposite trend was noted for those samples dried with hot air. Previous studies have revealed that the most common causes of color damage in the drying process are an excessively high temperature as well as an overly long drying time (12-14). However, those leaves dried with hot air produced a significantly higher $a^{*}$ value, while those which had been freeze-dried produced a lower $\mathrm{a}^{*}$ value $(\mathrm{p}<0.05)$. Youssef and Mokhtar (15) demonstrated that the hot-air-dried purslane leaves exhibited a higher $\mathrm{a}^{*}$ value than freeze-dried samples. On average, the 'Gabjubaekmok' persimmon leaf powder exhibited slightly higher color values (lightness, redness, and yellowness) than the other cultivars.

\section{Vitamin C content}

The effect of drying on the vitamin $\mathrm{C}$ content of the persimmon leaves is clearly shown in Figs. 1 and 2. There

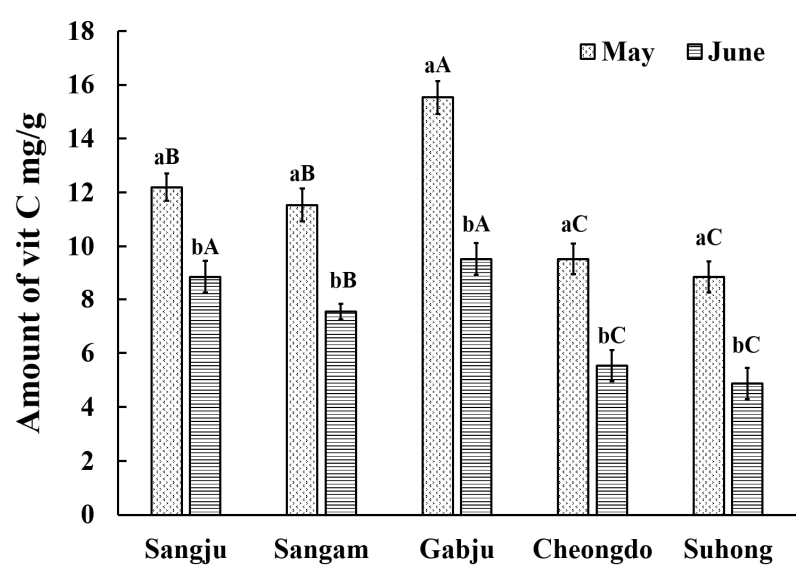

Fig. 1. Vitamin C contents $(\mathrm{mg} / \mathrm{g})$ of different persimmon leaves subjected to hot-air drying in May and June.

Sangju, Sangju-dungsi; Sangam, Sangam-dungsi; Gabju, Gabjubaekmok; Cheongdo, Cheongdobansi.

Values are given as the mean \pm SD for three measurements $(\mathrm{n}=3)$.

Lower case letters $(\mathrm{a}-\mathrm{b})$ within bars of the same cultivar with different harvesting time and capital alphabet letters $(\mathrm{A}-\mathrm{C})$ within bars of the different cultivars across same harvesting time are significantly different $(\mathrm{p}<0.05)$. 
Table 2. Effect of hot air drying and freeze drying on the color characteristics of different persimmon leaves

\begin{tabular}{|c|c|c|c|c|c|c|c|}
\hline \multirow{2}{*}{ Harvesting time } & \multirow{2}{*}{ Cultivar } & \multicolumn{3}{|c|}{ Hot air drying } & \multicolumn{3}{|c|}{ Freeze drying } \\
\hline & & $\mathrm{L}^{\star}$ value & $a^{*}$ value & $\mathrm{b}^{\star}$ value & $L^{*}$ value & $a^{\star}$ value & $b^{*}$ value \\
\hline \multirow{5}{*}{$25^{\text {th }}$ May (flowering) } & Sangju-dungsi & $52.44 \pm 0.36^{1)}$ & $2.22 \pm 0.01^{62)}$ & $13.96 \pm 0.30$ & $59.17 \pm 0.32^{\mathrm{c}}$ & $1.44 \pm 0.04^{\mathrm{d}}$ & $18.60 \pm 0.29^{b}$ \\
\hline & Sangam-dungsi & $54.07 \pm 0.85$ & $1.47 \pm 0.05^{\mathrm{c}}$ & $12.31 \pm 0.42$ & $62.14 \pm 0.39^{\mathrm{a}}$ & $1.42 \pm 0.02^{\mathrm{d}}$ & $20.13 \pm 0.16^{\mathrm{a}}$ \\
\hline & Cheongdobansi & $53.17 \pm 0.59$ & $2.15 \pm 0.09^{b}$ & $13.93 \pm 0.56$ & $57.92 \pm 0.07^{\mathrm{d}}$ & $2.06 \pm 0.01^{\mathrm{b}}$ & $15.96 \pm 0.02^{\mathrm{d}}$ \\
\hline & Gabjubaekmok & $54.07 \pm 0.28$ & $2.47 \pm 0.13^{\mathrm{a}}$ & $14.82 \pm 0.38$ & $60.61 \pm 0.24^{b}$ & $2.31 \pm 0.02^{\mathrm{a}}$ & $18.95 \pm 0.10^{b}$ \\
\hline & Suhong & $52.46 \pm 0.60$ & $2.02 \pm 0.03^{b}$ & $12.25 \pm 0.42$ & $60.29 \pm 0.29^{b}$ & $1.83 \pm 0.04^{\mathrm{c}}$ & $17.65 \pm 0.11^{\mathrm{c}}$ \\
\hline \multirow{5}{*}{$25^{\text {th }}$ June (fruiting) } & Sangju-dungsi & $51.34 \pm 0.09^{c}$ & $2.39 \pm 0.01^{\mathrm{b}}$ & $15.44 \pm 0.15^{\mathrm{a}}$ & $58.41 \pm 0.21$ & $0.67 \pm 0.02^{\mathrm{d}}$ & $18.72 \pm 0.06^{\text {ba }}$ \\
\hline & Sangam-dungsi & $52.71 \pm 0.19^{b}$ & $1.95 \pm 0.01^{\mathrm{c}}$ & $13.78 \pm 0.14^{c}$ & $59.36 \pm 0.35$ & $0.79 \pm 0.02^{c}$ & $18.44 \pm 0.11^{\mathrm{b}}$ \\
\hline & Cheongdobansi & $52.54 \pm 0.19^{b}$ & $1.98 \pm 0.01^{\mathrm{c}}$ & $14.75 \pm 0.23^{b}$ & $58.78 \pm 0.60$ & $1.00 \pm 0.02^{\mathrm{b}}$ & $17.57 \pm 0.27^{\mathrm{c}}$ \\
\hline & Gabjubaekmok & $53.68 \pm 0.19^{\mathrm{a}}$ & $2.51 \pm 0.05^{\mathrm{a}}$ & $15.51 \pm 0.24^{\mathrm{a}}$ & $58.95 \pm 0.19$ & $1.45 \pm 0.04^{\mathrm{a}}$ & $18.83 \pm 0.06^{\mathrm{ba}}$ \\
\hline & Suhong & $52.79 \pm 0.14^{b}$ & $1.84 \pm 0.02^{\mathrm{d}}$ & $15.16 \pm 0.20^{\mathrm{ba}}$ & $59.51 \pm 0.15$ & $0.82 \pm 0.01^{\mathfrak{c}}$ & $19.10 \pm 0.07^{\mathrm{a}}$ \\
\hline
\end{tabular}

${ }^{1)}$ Results are expressed as the mean \pm standard error of three measurements $(n=3)$.

${ }^{2}$ Lower case letters within column of the different cultivars across same harvesting time are significantly different $(p<0.05)$.

was no difference in the final vitamin $\mathrm{C}$ content regardless of whether the leaves were hot-air dried or freeze-dried, or whether they were collected in the flowering (late May) or fruiting (late June) stages. Matsuura et al. (16) noted that drying led to a reduction in the vitamin $\mathrm{C}$ content, with fresh persimmon leaves having a relatively high vitamin $C$ content. The loss of vitamin $\mathrm{C}$ as a result of the drying depends on the type of the drying that is applied and the physical properties of the products (17). Although, freeze-drying is regarded as being one of the best drying techniques for maintaining the characteristics of the samples, in the present

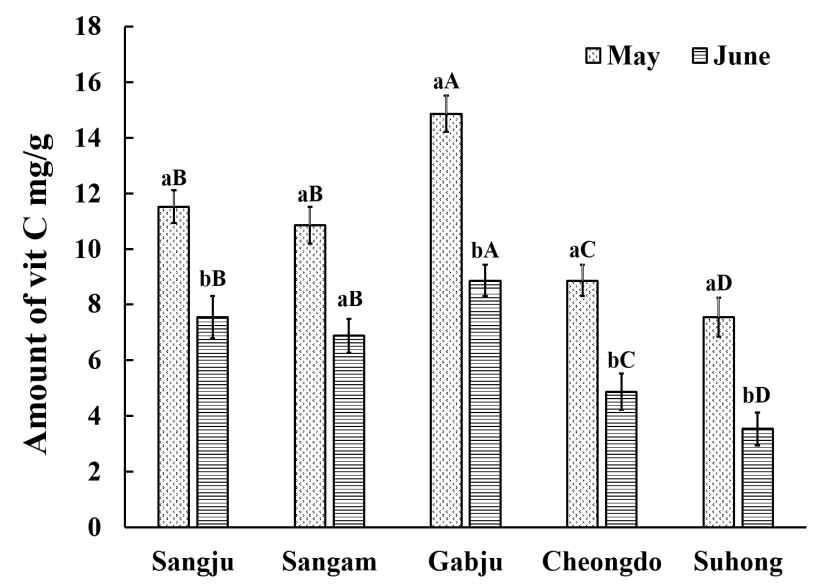

Fig. 2. Vitamin $\mathrm{C}$ contents ( $\mathrm{mg} / \mathrm{g})$ of different persimmon leaves by freeze-drying treatment in May and June.

Sangju, Sangju-dungsi; Sangam, Sangam-dungsi; Gabju, Gabjubaekmok; Cheongdo, Cheongdobansi.

Values are mean $\pm S D$ of three measurements $(n=3)$. Lower case letters $(a-b)$ within bars of the same cultivar with different harvesting time and capital alphabet letters $(\mathrm{A}-\mathrm{D})$ within bars of the different cultivars across same harvesting time are significantly different $(\mathrm{p}<0.05)$. study loss was not an issue. Michalska et al. (18) found that freeze-dried samples had a lower amount of vitamin $\mathrm{C}$ than those dried using another means. It is possible that increased enzymatic activity during the freeze drying and upon thawing could lead to degradation of the ascorbic acid. Also, vitamin $\mathrm{C}$ retention may be adversely affected by the extended drying duration $(72 \mathrm{~h}$ ) compared to hot-air drying (30 min). Hence, in one respect it can be said that hot-air drying is superior in terms of retaining the vitamin $\mathrm{C}$ content in persimmon leaves. Furthermore, freeze drying always regarded as being the more expensive method.

However, the amount of vitamin $\mathrm{C}$ was highest in the 'Gabjubaekmok' persimmon leaves while the lowest vitamin C content was observed in 'Suhong' persimmon leaves, regardless of the harvesting stage $(\mathrm{p}<0.05)$. A similar vitamin $\mathrm{C}$ content was observed for the 'Cheongdobansi' and 'Suhong' leaves that had been hot-air dried, regardless of the harvesting time. After freeze drying, the vitamin $\mathrm{C}$ content could be ranked, in descending order, as 'Gabjubaekmok' > 'Sangju-dungsi' > 'Sangam-dungsi' > 'Cheongdobansi' > 'Suhong'. Meanwhile, higher levels of vitamin C were noted in the flowering phase compared to the fruiting phase. Kim et al. (19) and Chung et al. (20) reported that the vitamin $\mathrm{C}$ content of the persimmon leaves began to fall after $20^{\text {th }}$ June. However, this finding was not confirmed in the present study. A possible reason for this effect could be the movement of the vitamin $\mathrm{C}$ from the leaves to the fruits at the fruiting stage. Another possible reason for the differences between harvesting times can be associated with the plant physiological characteristics, light intensity, environmental conditions and 
the amount of nitrogen present in the soil (4).

\section{Mineral content}

Changes in the mineral contents of the persimmon leaves treated with different drying methods are listed in Table 3. The hot-air and freeze-drying both had a significant effect on the mineral concentration, in that the reduction in the moisture content as a result of the drying greatly increased the concentration of the nutrients (21). These results pointed to freeze-drying being the most efficient whereas hot-air drying was the least efficient with respect to the mineral content $(p<0.05)$. This was most likely due to the absence of heat and photoreactions during the freeze-drying process. Ladan et al. (22) reported that the application of heat decreases the nutrient content of tomatoes. Our findings were in good agreement with those of Umar et al. (23), who reported that freeze-dried moringa leaf has a higher mineral content than leaves dried using other techniques.

It was determined that the levels of $\mathrm{Na}, \mathrm{Fe}, \mathrm{Cu}$, and $\mathrm{Zn}$ decreased from May to June. Similar results, again for persimmon leaves, were reported by Clark and Smith (24) and Yildiz and Kaplankiran (25), They went on to state that the contents of these minerals decreased throughout the growing season. Possible reasons for this trend could be the movement of the minerals from the leaves to the shoots and, finally, into the fruits. Yildiz and Kaplankiran (25) stated that the amount of $\mathrm{Na}, \mathrm{Fe}, \mathrm{Cu}$, and $\mathrm{Zn}$ in persimmon shoots increased after June, whereas Clark and Smith (26) showed that the nutrient level $(\mathrm{Fe}, \mathrm{Cu}$, and $\mathrm{Zn})$ in persimmon fruits increased during fruiting. Moreover, the decline in the $\mathrm{Fe}$ content is affected by other factors including soil moisture, salinity, carbonate levels in the soil, and decreasing temperature, whereas the level of $\mathrm{Cu}$ and $\mathrm{Zn}$ uptake is influenced by the plant species as well as the cultivar (27).

Persimmon leaves are noted for their high $\mathrm{K}$ content, although the amounts of $\mathrm{Cu}$ and $\mathrm{Zn}$ are not so high. The highest $\mathrm{Na}, \mathrm{Fe}$, and $\mathrm{Zn}$ levels were recorded for the 'Sangam-dungsi' leaf, regardless of whether it had been

Table 3. Effect of hot-air drying and freeze-drying on mineral contents of different persimmon leaves

\begin{tabular}{|c|c|c|c|c|c|c|c|c|c|c|}
\hline \multirow{2}{*}{$\begin{array}{l}\text { Drying } \\
\text { method }^{1)}\end{array}$} & \multirow{2}{*}{$\begin{array}{l}\text { Harvesting } \\
\text { stage }\end{array}$} & \multicolumn{9}{|c|}{ Element $(\mathrm{mg} / 100 \mathrm{~g})$} \\
\hline & & Cultivar & $\mathrm{Na}$ & $\mathrm{Mg}$ & K & $\mathrm{Ca}$ & $\mathrm{Mn}$ & $\mathrm{Fe}$ & $\mathrm{Cu}$ & $\mathrm{Zn}$ \\
\hline \multirow{10}{*}{$\mathrm{HAD}$} & \multirow{5}{*}{$\begin{array}{c}25^{\text {th }} \text { May } \\
\text { (flowering) }\end{array}$} & Sangju-dungsi & $4.16 \pm 0.18^{2) e 3)}$ & $77.22 \pm 1.16^{c}$ & $446.37 \pm 10.84^{d}$ & $272.45 \pm 6.28^{b}$ & $8.49 \pm 0.02^{\mathrm{d}}$ & $2.97 \pm 0.02^{\mathrm{d}}$ & $3.07 \pm 0.01^{\mathrm{a}}$ & $0.84 \pm 0.01^{\mathrm{c}}$ \\
\hline & & Sangam-dungsi & $9.71 \pm 0.22^{\mathrm{a}}$ & $108.0 \pm 2.99^{\mathrm{a}}$ & $845.97 \pm 22.99^{\mathrm{a}}$ & $418.98 \pm 18.07^{\mathrm{a}}$ & $9.91 \pm 0.05^{\mathrm{c}}$ & $6.11 \pm 0.01^{\mathrm{a}}$ & $0.89 \pm 0.01^{\mathrm{c}}$ & $1.49 \pm 0.01^{\mathrm{a}}$ \\
\hline & & Cheongdobansi & $5.98 \pm 0.08^{\mathrm{c}}$ & $97.65 \pm 2.04^{b}$ & $767.44 \pm 23.57^{\mathrm{b}}$ & $277.42 \pm 14.87^{\mathrm{b}}$ & $35.98 \pm 0.23^{\mathrm{a}}$ & $3.92 \pm 0.04^{b}$ & $0.61 \pm 0.01^{\mathrm{e}}$ & $1.02 \pm 0.01^{b}$ \\
\hline & & Gabjubaekmok & $8.81 \pm 0.19^{b}$ & $67.85 \pm 1.60^{\mathrm{d}}$ & $517.45 \pm 12.35^{\mathrm{c}}$ & $268.47 \pm 10.12^{\mathrm{b}}$ & $15.07 \pm 0.09^{b}$ & $3.09 \pm 0.04^{\mathrm{c}}$ & $0.82 \pm 0.01^{\mathrm{d}}$ & $0.64 \pm 0.00^{e}$ \\
\hline & & Suhong & $4.83 \pm 0.03^{\mathrm{d}}$ & $66.90 \pm 2.01^{b}$ & $442.41 \pm 14.36^{\mathrm{d}}$ & $287.63 \pm 17.25^{b}$ & $3.81 \pm 0.02^{\mathrm{e}}$ & $2.62 \pm 0.01^{\mathrm{e}}$ & $1.15 \pm 0.01^{\mathrm{b}}$ & $0.71 \pm 0.01^{\mathrm{d}}$ \\
\hline & \multirow{5}{*}{$\begin{array}{l}25^{\text {th }} \text { June } \\
\text { (fruiting) }\end{array}$} & Sangju-dungsi & $3.60 \pm 0.08^{c}$ & $93.44 \pm 1.85^{\mathrm{d}}$ & $495.28 \pm 14.23^{\mathrm{e}}$ & $378.29 \pm 15.93^{\mathrm{c}}$ & $11.94 \pm 0.03^{\mathrm{d}}$ & $2.42 \pm 0.02^{\mathrm{c}}$ & $0.48 \pm 0.01^{b}$ & $0.51 \pm 0.01^{\mathrm{d}}$ \\
\hline & & Sangam-dungsi & $5.57 \pm 0.20^{\mathrm{a}}$ & $114.04 \pm 1.33^{c}$ & $897.61 \pm 13.53^{b}$ & $451.55 \pm 8.28^{b}$ & $20.9 \pm 0.09^{c}$ & $2.25 \pm 0.01^{\mathrm{e}}$ & $0.40 \pm 0.01^{\mathrm{d}}$ & $1.05 \pm 0.01^{\mathrm{a}}$ \\
\hline & & Cheongdobansi & $4.11 \pm 0.16^{b}$ & $142.94 \pm 2.16^{\mathrm{a}}$ & $1,057.60 \pm 16.38^{\mathrm{a}}$ & $370.67 \pm 7.29^{c}$ & $56.26 \pm 0.35^{\mathrm{a}}$ & $3.81 \pm 0.02^{\mathrm{a}}$ & $0.81 \pm 0.01^{\mathrm{a}}$ & $0.81 \pm 0.01^{b}$ \\
\hline & & Gabjubaekmok & $4.26 \pm 0.04^{b}$ & $124.55 \pm 2.80^{\mathrm{b}}$ & $831.11 \pm 22.49^{c}$ & $499.91 \pm 16.91^{\mathrm{a}}$ & $23.50 \pm 0.11^{\mathrm{b}}$ & $3.05 \pm 0.01^{b}$ & $0.31 \pm 0.01^{\mathrm{e}}$ & $0.64 \pm 0.01^{c}$ \\
\hline & & Suhong & $2.64 \pm 0.10^{d}$ & $111.41 \pm 2.47^{\mathrm{c}}$ & $665.78 \pm 12.78^{d}$ & $474.67 \pm 17.45^{\text {ba }}$ & $6.26 \pm 0.02^{\mathrm{e}}$ & $2.34 \pm 0.01^{\mathrm{d}}$ & $0.41 \pm 0.01^{\mathrm{c}}$ & $0.56 \pm 0.00^{e}$ \\
\hline \multirow{10}{*}{ FD } & \multirow{5}{*}{$\begin{array}{r}25^{\text {th }} \text { May } \\
\text { (flowering) }\end{array}$} & Sangju-dungsi & $7.56 \pm 0.26^{d}$ & $75.86 \pm 1.53^{\mathrm{d}}$ & $611.31 \pm 9.19^{d}$ & $255.70 \pm 7.46^{\mathrm{d}}$ & $10.40 \pm 0.01^{\mathrm{d}}$ & $4.08 \pm 0.15^{\mathrm{c}}$ & $5.80 \pm 0.02^{\mathrm{a}}$ & $0.86 \pm 0.01^{\mathrm{d}}$ \\
\hline & & Sangam-dungsi & $12.63 \pm 0.33^{\mathrm{a}}$ & $153.33 \pm 2.85^{\mathrm{a}}$ & $971.58 \pm 28.84^{\mathrm{a}}$ & $591.25 \pm 24.92^{\mathrm{a}}$ & $15.49 \pm 0.07^{\mathrm{c}}$ & $13.77 \pm 0.06^{\mathrm{a}}$ & $1.86 \pm 0.02^{d}$ & $2.34 \pm 0.01^{\mathrm{a}}$ \\
\hline & & Cheongdobansi & $7.05 \pm 0.31^{\mathrm{d}}$ & $93.90 \pm 1.82^{\mathrm{c}}$ & $783.49 \pm 16.63^{c}$ & $264.80 \pm 8.38^{\mathrm{d}}$ & $36.49 \pm 0.28^{\mathrm{a}}$ & $4.46 \pm 0.03^{b}$ & $2.64 \pm 0.01^{\mathrm{c}}$ & $1.29 \pm 0.01^{b}$ \\
\hline & & Gabjubaekmok & $10.69 \pm 0.35^{b}$ & $101.82 \pm 1.77^{\mathrm{b}}$ & $888.22 \pm 12.44^{b}$ & $360.65 \pm 18.84^{\mathrm{b}}$ & $22.33 \pm 0.06^{b}$ & $3.44 \pm 0.02^{\mathrm{d}}$ & $1.54 \pm 0.01^{\mathrm{e}}$ & $1.27 \pm 0.01^{c}$ \\
\hline & & Suhong & $8.64 \pm 0.39^{c}$ & $69.07 \pm 1.28^{\mathrm{e}}$ & $538.24 \pm 11.34^{\mathrm{e}}$ & $294.60 \pm 11.01^{\mathrm{c}}$ & $4.78 \pm 0.02^{\mathrm{e}}$ & $4.57 \pm 0.04^{\mathrm{b}}$ & $3.10 \pm 0.01^{b}$ & $0.76 \pm 0.00^{e}$ \\
\hline & \multirow{5}{*}{$\begin{array}{l}25^{\text {th }} \text { June } \\
\text { (fruiting) }\end{array}$} & Sangju-dungsi & $5.14 \pm 0.18^{d}$ & $186.61 \pm 2.53^{\mathrm{a}}$ & $959.15 \pm 11.77^{\mathrm{c}}$ & $645.71 \pm 13.98^{\mathrm{a}}$ & $21.27 \pm 0.12^{\mathrm{d}}$ & $3.84 \pm 0.02^{\mathrm{a}}$ & $0.73 \pm 0.01^{\mathrm{d}}$ & $0.63 \pm 0.00^{\mathrm{d}}$ \\
\hline & & Sangam-dungsi & $6.73 \pm 0.12^{\mathrm{b}}$ & $174.29 \pm 4.50^{b}$ & $1,484.30 \pm 28.62^{\mathrm{a}}$ & $647.38 \pm 28.82^{\mathrm{a}}$ & $34.69 \pm 0.13^{b}$ & $2.73 \pm 0.01^{\mathrm{e}}$ & $1.05 \pm 0.01^{\mathrm{b}}$ & $1.19 \pm 0.01^{\mathrm{a}}$ \\
\hline & & Cheongdobansi & $5.50 \pm 0.22^{c}$ & $182.70 \pm 3.97^{\mathrm{a}}$ & $1,237.49 \pm 36.26^{b}$ & $444.96 \pm 12.76^{c}$ & $74.75 \pm 1.30^{\mathrm{a}}$ & $3.57 \pm 0.02^{\mathrm{b}}$ & $0.86 \pm 0.01^{\mathrm{c}}$ & $0.82 \pm 0.01^{\mathrm{b}}$ \\
\hline & & Gabjubaekmok & $5.60 \pm 0.20^{c}$ & $139.81 \pm 2.04^{c}$ & $1,006.26 \pm 25.79^{c}$ & $525.13 \pm 14.19^{b}$ & $27.80 \pm 0.19^{c}$ & $3.17 \pm 0.01^{\mathrm{c}}$ & $0.50 \pm 0.01^{\mathrm{e}}$ & $0.64 \pm 0.01^{\mathrm{d}}$ \\
\hline & & Suhong & $8.50 \pm 0.18^{a}$ & $109.18 \pm 2.44^{\mathrm{d}}$ & $634.91 \pm 22.94^{\mathrm{d}}$ & $447.14 \pm 17.30^{\mathrm{c}}$ & $7.86 \pm 0.01^{\mathrm{e}}$ & $2.91 \pm 0.02^{\mathrm{d}}$ & $1.06 \pm 0.01^{\mathrm{a}}$ & $0.66 \pm 0.01^{c}$ \\
\hline
\end{tabular}

${ }^{1)} \mathrm{HAD}$, hot-air drying; FD, freeze-drying.

${ }^{2)}$ Results are expressed as the mean $\pm \mathrm{SD}$ of three measurements $(\mathrm{n}=3)$

${ }^{3)}$ Lower case letters within column of the different cultivars across same harvesting stage are significantly different $(\mathrm{p}<0.05)$. 
hot-air or freeze-dried, relative to the other cultivars during the flowering (late May) stage. However, the $\mathrm{Na}$ and Fe levels varied depending on the cultivars during the fruiting (late June) stage, with the 'Sangam-dungsi' cultivar being superior in terms of $\mathrm{Zn}$ content, regardless of the harvesting stage. Moreover, the level of $\mathrm{Cu}$ was the highest in the 'Sangju-dungi' leaves collected at the flowering stage and treated by both types of drying, while this figure varied at the fruiting stage. The 'Sangju-dungi' and 'Gabjubaekmok' cultivars proved to have poor $\mathrm{Na}$ and $\mathrm{Cu}$ contents, respectively.

It was found that the $\mathrm{Mg}, \mathrm{Ca}, \mathrm{K}, \mathrm{Mn}$, and $\mathrm{Al}$ levels increased from May to June. These findings were in good agreement with the findings of Clark and Smith (24) and Yildiz and Kaplankiran (25), who stated that the mineral (Mg, $\mathrm{Ca}$, and $\mathrm{Mn}$ ) contents of persimmon leaves increased during the growing season. Moreover, Liu and Wang (28), Rehalia and Sandhu (29), and Fernandez-Escobar et al. (30) reported that the amount of $\mathrm{Mg}$ and $\mathrm{Ca}$ in persimmon leaves increased throughout the growing season as a result of the transpiration stream carrying water and nutrients to the leaves throughout the growing season, such that the $\mathrm{Mg}$ content steadily increased (29). Trees take up calcium and magnesium from the soil at rates that vary with the temperature. However, Fernandez-Escobar et al. (30) reported that the amount of $\mathrm{Mn}$ and $\mathrm{K}$ in olive leaves increased steadily from the beginning of the season, given that the manganese concentration in the leaves tends to rise over time in deciduous fruit plants $(31,32)$ and plays an important role in photosynthesis. Also, the amount of Mn increases during the growing season due to the increase in the soil temperature. Potassium is a highly mobile macronutrient which plays a vital role in protein synthesis, carbohydrate translocation, osmoregulation, enzyme activation, stomatal movement, and cell turgidity (33). However, Yildiz and Kaplankiran (25) showed that the amount of $\mathrm{K}$ declined during the growing season whereas the opposite trend was observed in the present study. This can probably be attributed to differences in the soil types, fertilizers, management, and climate. Tanaka et al. (34) stated that, to fulfill the requirements of fruit development, large amounts of potassium would need to be transferred from other parts of the plant.

The highest amounts of $\mathrm{Mg}, \mathrm{K}$, and $\mathrm{Ca}$ were observed in 'Sangam-dungsi' persimmon leaves collected at the flowering stage, regardless of the drying technique, while these figures varied during the fruiting stage. On average, 'Suhong' persimmon leaves have come to be regarded as an inferior cultivar in terms of the $\mathrm{Mg}, \mathrm{K}$, and $\mathrm{Ca}$ content. Furthermore, the 'Cheongdobansi' and 'Suhong' cultivars are superior and inferior, respectively, in terms of Mn content, regardless of whether they are collected in the flowering or fruiting stages, and regardless of the drying method that is applied.

\section{Conclusion}

We observed significant variations in the color and moisture, vitamin $\mathrm{C}$, and mineral contents of leaves collected from five persimmon cultivars. It was found that freeze-drying was superior to hot-air drying in terms of preserving the mineral content and color. However, hot-air drying proved to be superior in terms of maintaining the vitamin $\mathrm{C}$ content due to the short drying time, which also reduced the energy consumption, although very similar results could be attained by freeze-drying. Our results suggest that 'Gabjubaekmok' is the superior cultivar, while late May is the optimum harvesting time, with respect to the vitamin $\mathrm{C}$ content. On the other hand, the amounts of most of the macronutrients increased from May to June, while the opposite was true for the micronutrients.

The amounts of copper and zinc in the persimmon leaves were lower than those of the other elements. Therefore, farmers should apply basic copper- and zinc-based fertilizer during the growing season. Our results would help persimmon growers to identify a cultivar and harvest time that would allow them to produce better-quality persimmon leaves. Further work is required to optimize the potential differences in the mineral contents of persimmon leaves collected from different cultivars and at different harvest times.

\section{Acknowledgment}

This Research was supported by Kyungpook National University Research Fund, 2017.

\section{References}

1. Matsuo T, Ito S (1978) The chemical structure of kaki-tannin from immature fruit of the persimmon (Diospyros kaki L.). Agric Biol Chem, 42, 1637-1643 2. Jo C, Son JH, Shin MG, Byun MW (2003) Irradiation 
effects on color and functional properties of persimmon (Diospyros kaki L. folium) leaf extract and licorice (Glycyrrhiza Uralensis Fischer) root extract during storage. Radiat Phys Chem, 67, 143-148

3. Moser U, Bendich A (1991) Vitamin C. In: Handbook of Vitamins, Machlin LJ (Editor), Marcel Dekker, New York, NY, USA, p 195-224

4. Lee SK, Kader AA (2000) Preharvest and postharvest factors influencing vitamin $\mathrm{C}$ content of horticultural crops. Postharvest Biol Technol, 20, 207-220

5. Jones JB (1985) Soil testing and plant analysis: guides to the fertilization of horticultural crops. Hortic Rev, 7, $1-68$

6. Baxter GF, Sumeray MS, \& Walker JM (1996) Infarct size and magnesium: insights into LIMIT-2 and ISIS-4 from experimental studies. Lancet, 348, 1424-1426

7. Wills ED (1985) Metal catalysts in the diet. In: Oxidative stress, Helmut S (Editor), Academic Press, London, UK, p 206-208

8. Martinez-Las HR, Heredia A, Castello ML, Andres A (2014) Influence of drying method and extraction variables on the antioxidant properties of persimmon leaves. Food Bioscience, 6, 1-8

9. AOAC (2000) Official method of analysis $16^{\text {th }}$ ed, Association of Official Analytical Chemists, Washington DC, USA

10. Khan MMR, Rahman MM, Islam MS, Begum SA (2006) A simple UV-spectrophotometric method for the determination of vitamin $\mathrm{C}$ content in various fruits and vegetables at Sylhet area in Bangladesh. J Biol Sci, 6, 388-392

11. Bond B, Fernandez DR, Vanderjagt DJ, Williams M, Huang YS, Chuang LT, Millson M, Andrews R, Glew RH (2005) Fatty acid, amino acid and trace mineral analysis of three complementary foods from Jos, Nigeria. J Food Compos Anal, 18, 675-690

12. Arslan D, Ozcan MM (2008) Evaluation of drying methods with respect to drying kinetics, mineral content and colour characteristics of rosemary leaves. Energy Convers Manage, 49, 1258-1264

13. Arabhosseini A, Padhye S, Huisman W, Boxtel AV, Muller J (2011) Effect of drying on the color of Tarragon (Artemisia dracunculus L.) leaves. Food Bioprocess Technol, 4, 1281-1287

14. Rahimmalek M, Goli SM (2013) Evaluation of six drying treatments with respect to essential oil yield, composition and color characteristics of Thymys Daenensis subsp. daenensis. Celak leaves. Ind Crops Prod, 42, 613-619

15. Youssef KM, Mokhtar SM (2014) Effect of drying methods on the antioxidant capacity, color and phytochemicals of Portulaca oleracea L. Leaves. J Nutr Food Sci, 4, 1-6

16. Matsuura S, Asano K, Ohba K, Mizuno M (1971) Studies on the components of the leaves of Diospyros kaki Thunb. Yakugaku Zasshi, 91, 905-906

17. Goula AM, Adamopoulos KG (2006) Retention of ascorbic acid during drying of tomato halves and tomato pulp. Drying Technol, 24, 57-64

18. Michalska A, Wojdylo A, Lysiak GP, Figiel A (2017) Chemical composition and antioxidant properties of powders obtained from different Plum juice formulations. Int $\mathrm{J}$ Mol Sci, 18, 1-14

19. Kim JK, Lee WY (2002) Changes of chemical components in Persimmon leaves (Diospyros kaki Thunberg) during growth. J East Asian Soc Diet Life, $12,32-37$

20. Chung SH, Moon KD, Kim JK, Seong JH, Sohn TH (1994) Changes of chemical components in persimmon leaves during growth for processing persimmon leaves tea. Korean J Food Sci Technol, 26, 141-146

21. Morris A, Barnett A, Burrows OJ (2004) Effect of processing on nutrient content of foods. Cajarticles, 37, $160-164$

22. Ladan MJ, Abubakar MG, Lawal M (1997) Effect of solar drying on the nutrient composition of tomatoes. Nig J Renew Energy, 5, 67-69

23. Umar YB, Isyaku AH, Mohammed-Dabo IA, Bilal S, Mashi AH, Adamu MS (2015) Effect of drying techniques on the nutrients of moringa leaves. Federal University of Technology, September 3, Minna, Nigeria

24. Clark CJ, Smith GS (1990) Seasonal changes in the mineral nutrient content of persimmon leaves. Sci Hortic, 42, 85-97

25. Yildiz E, Kaplankiran M (2013) Seasonal variations in mineral nutrients in leaves and shoots of some persimmon cultivars grown in Turkey. Acta Hortic, 966, 351-357

26. Clark CJ, Smith GS (1990) Seasonal changes in the composition, distribution and accumulation of mineral nutrients in persimmon fruit. Sci Hortic, 42, 99-111

27. Kacar B, Katkat AV (2007) Plant nutrient. Nobel science and research center publication No- 49, Ankara, Turkey, p 659

28. Liu YJ, Wang WJ (1989) Seasonal changes in the contents of the major nutrient elements in the leaves and 
the fruits of persimmon tree. Acta Hortic Sinica, 16, 103-113

29. Rehalia AS, Sandhu RD (2005) Standardization of foliar sampling technique for macro-nutrients in persimmon (Diosypros kaki L.) cv. Hachiya. Acta Hortic, 696, 265-268

30. Fernandez-Escobar R, Moreno R, Garcia-Creus M (1999) Seasonal changes of mineral nutrients in olive leaves during the alternate-bearing cycle. Sci Hortic, 82, 25-45

31. Buwalda JG, Meekings JS (1990) Seasonal accumulation of mineral nutrients in leaves and fruit of Japanese pear (Pyrus serotine Rehd). Sci Hortic, 41, 209-222

32. Brown PH (1994) Seasonal variations in fig (Ficus carica L.) leaf nutrient concentrations. HortSci, 29, 871-873

33. Pallardy SG (2008) Mineral nutrition. In: Physiology of woody plants, Elsevier, Cambridge, MA, USA, p 256-285

34. Tanaka K, Aoki M, Kinbara T, Tsuda K, Kawabuchi A (1976) Studies of the absorption of essential nutrients by kaki (Diospyros kaki L.) in water culture. Res Bull Aichi-Ken Agric Res Cent Ser B, 8, 74-84 